ARTIGO

(a) (1) https://creativecommons.org/licenses/by/4.0/

\title{
QUACKENBOS COMO ANTÍDOTO A ORTIZ \& PARDAL: O ENSINO DA GRAMÁTICA DA LÍNGUA PORTUGUESA NO PARECER DE RUY BARBOSA, 1882
}

\author{
MIRIAN JORGE WARDE ${ }^{1}$ \\ ORCID: https://orcid.org/0000-0002-1119-6729 \\ FERNANDO RODRIGUES DE OLIVEIRA ${ }^{2}$ \\ ORCID: https://orcid.org/0000-0002-5609-550X
}

\begin{abstract}
RESUMO: O objetivo deste artigo é contribuir para as já avançadas pesquisas, no Brasil, referentes ao método intuitivo. São examinados dois livros citados por Ruy Barbosa em seu Parecer de 1882 sobre o ensino primário no Município da Corte: Illustrated lessons in our lenguage; or how to speak and write correctly. Designed to teach english grammar, without technicalities, de George Payn Quackenbos, recomendado por Barbosa como antídoto a Grammatica analytica e explicativa da lingua portugueza, de José Ortiz e Candido Pardal, em circulação nos anos de 1870 e 1880, especialmente nas escolas primárias do Rio de Janeiro. Sobre Grammatica analytica, destaca-se sua organização fundada no conceito de gramática como arte de escrever e falar bem, o que denota sua filiação ao modelo geral e filosófico greco-latino, portanto, seu descompasso em relação à renovação científica que vinha ocorrendo na Linguística no século XIX. Para apresentação contextuada das Illustrated lessons... - e considerando que o seu autor ainda não ganhou estudos no Brasil sobre o ensino de gramática, composição e áreas adjacentes, e sobre o método intuitivo -, o artigo situa esse livro em relação às demais publicações de Quackenbos, bem como o seu enraizamento intelectual no "enlightenment" escocês e sua declarada adesão às lições de coisas (object lessons). Com isso, verifica-se em Ruy Barbosa um grau razoavelmente alto de consistência nas críticas que enceta contra o conservadorismo linguístico presente na Instrução Primária da Corte e sua atualidade em relação aos estudos então mais recentes que dão base a novas propostas pedagógicas, ditas modernas.
\end{abstract}

Palavras-chave: George Payn Quackenbos, método intuitivo, Ruy Barbosa, gramática, língua portuguesa.

\section{QUACKENBOS AS AN ANTIDOTE TO ORTIZ \& PARDAL: TEACHING PORTUGUESE GRAMMAR IN THE EXPERT OF RUY BARBOSA, 1882}

\begin{abstract}
The purpose of this article is to contribute to the already advanced research in Brazil regarding the intuitive method. We examine two books cited by Ruy Barbosa in his 1882 Opinion about primary education in the Municipality of Corte: Illustrated lessons in our language; or how to speak and write correctly. Designed to teach English grammar, without technicalities, by George Payn Quackenbos, recommended by Barbosa as an antidote to Grammatica analytica e explicativa da lingua portuguesa (Analytical and explanatory grammar of the Portuguese language), by José Ortiz and Candido Pardal, in circulation in the 1870s and 1880s, especially in the elementary school of Rio de Janeiro. About Grammatica analytica (Analytical Grammar), we highlight its organization based on the concept of grammar as the art of writing and speaking well, which denotes its affiliation to the general and philosophical Greco-Latin model, therefore,
\end{abstract}

\footnotetext{
${ }^{1}$ Universidade Federal de São Paulo, Guarulhos, SP, Brasil. <mjwarde@uol.com.br>

${ }^{2}$ Universidade Federal de São Paulo, Guarulhos, SP, Brasil. <fer.tupa@gmail.com> Educação em Revista|Belo Horizonte|v.37|e26782|2021
} 
its disagreement with the scientific renovation that was occurring in Linguistics in the 19th century. For contextualized presentation of the Illustrated lessons... - and considering that its author has not yet gained studies in Brazil on the teaching of grammar, composition and adjacent areas, and on the intuitive method -, the article situates this book in relation to Quackenbos' other publications, as well as his intellectual roots in the Scottish "enlightenment" and his declared adherence to the object lessons. Thus, we can verify that Ruy Barbosa's criticism against the linguistic conservatism present in the Court's Primary Instruction is reasonably consistent and up-to-date in relation to the most recent studies that provide the basis for new, so-called modern, pedagogical proposals.

Keywords: George Payn Quackenbos, intuitive method, Ruy Barbosa, grammar, Portuguese language.

\section{QUACKENBOS COMO ANTÍDOTO A ORTIZ \& PARDAL: LA ENSEÑANZA DE LA GRAMÁTICA DE LA LENGUA PORTUGUESA EN EL PARECER DE RUY BARBOSA, 1882}

RESÚMEN: El objetivo de este artículo es contribuir para las ya avanzadas investigaciones en Brasil, referentes al método intuitivo. Se examinan dos libros citados por Ruy Barbosa en su Parecer de 1882 sobre la enseñanza primaria en el Municipio de la Corte: Illustrated lessons in our lenguage, de George Payn Quackenbos, recomendado por Barbosa como antídoto a la Grammatica analytica..., de Ortiz y Pardal en circulación en los años de 1870 y 1880, especialmente en las escuelas primarias de Rio de Janeiro. Se destaca en Grammatica analytica, su organización fundada en el concepto de gramática como arte de escribir y hablar bien, lo que denota su proximidad al modelo general y filosófico grecolatino; por tanto, su descompaso en relación a la renovación científica que venía ocurriendo en la Linguística en el siglo XIX. Para la presentación contextualizada de las Illustrated lessons... - y considerando que su autor aún no ganó estudios en Brasil sobre la enseñanza de gramática, composición y áreas adyacentes, y sobre el método intuitivo -, el artículo situa ese libro en relación a las demás publicaciones de Quackenbos, bien como a su enraizamiento intelectual en el "enlightenment" escocés y su declarada adesión a las lecciones de cosas (object lessons). Se verifica así en Ruy Barbosa, un grado razonablemente alto de consistencia en las críticas que enceta contra el conservadorismo linguístico presente en la Instrucción Primaria de la Corte y su actualidad en relación a los estudios entonces más recientes que dan base a nuevas propuestas pedagógicas dichas modernas.

Palabras clave: George Payn Quackenbos, método intuitivo, Ruy Barbosa, gramática, lengua portuguesa. 


\section{INTRODUÇÃO}

No ano de 1882, Ruy Barbosa, então deputado e membro da Comissão da Instrução Pública, apresentou à Câmara dos Deputados do Império do Brasil dois pareceres, um sobre o ensino primário e outro sobre o ensino secundário e superior. Com relação ao primeiro parecer destinado ao ensino primário do Município da Corte, Ruy Barbosa o dividiu em 18 partes. A sétima parte foi dedicada aos "Methodos e Programma Escolar", considerada por Barbosa um dos mais importantes pilares de toda a reforma escolar (BARBOSA, 1883). A sétima parte, por sua vez, foi dividida em 12 parágrafos, dos quais o quarto - "Lições de coisas. Methodo intuitivo" - e o quinto - "Lingua materna. Grammatica" - são os que aqui interessam.

Para tratar da "Língua materna", Barbosa cita aproximadamente 32 autores e 40 títulos em notas de rodapé. Nessa parte, há muito mais referências ao que se possa chamar de "ensaios acadêmicos" ou "relatos científicos" do que a relatórios de trabalho e de observação. Com isso, Barbosa mobiliza número maior de estudiosos que ganharam, com o tempo, o perfil de "especialistas" no assunto.

Quanto à nacionalidade dos autores, por nascimento ou adoção, Barbosa se refere a: 16 franceses; três suíços, e idêntico número de belgas e estadunidenses, além de dois ingleses e um alemão ${ }^{3}$. George Payn Quackenbos é um dos três estadunidenses presentes nas notas do parágrafo quinto; o seu nome e o título de seu manual - Illustrated lessons in our lenguage; or how to speak and write correctly. Designed to teach english grammar, without technicalities - aparecem apenas em duas notas. Autor e obra poderiam permanecer despercebidos não fosse o lugar estratégico que Ruy Barbosa a eles confere ao tratar do ensino da língua materna. O livro de Quackenbos é usado para rebater a Grammatica analytica e explicativa da língua portugueza (1872), de José Ortiz e Candido Pardal, cujos nomes, há de se salientar, o Barbosa sequer menciona.

Ruy Barbosa aponta a Grammatica Analytica..., de Ortiz e Pardal, como "corpo de delito" dos erros que estariam cometendo no ensino da língua materna por meio da gramática e indica Illustrated lessons in our lenguage..., de Quackenbos, como antídoto.

O objetivo deste artigo, ao por em tela os dois livros, é acrescentar novos elementos aos estudos já avançados no Brasil em torno do método intuitivo, destacadamente os de Valdemarin (2020; 2001; 2000a; 2000b; 1998) que, em muitos, se reporta aos pareceres de Ruy Barbosa. A originalidade deste estudo recai especialmente sobre G. P. Quackenbos e suas lições ilustradas, uma vez que a Grammatica analytica... ou seus autores já foram objeto de pesquisas aqui incorporadas na medida do cabível (BORGES, 2014; 2008; LEMOS, 2011; 2006; MARTINEZ, 1998; TEIXEIRA, 2016; 2008; SCHUELER, 2009).

\section{CONTROVÉRSIAS EM TORNO DA GRAMMATICA ANALYTICA..., DE ORTIZ \& PARDAL: AS CRÍTICAS DE RUY BARBOSA}

Ruy Barbosa colhe nos exemplos estrangeiros manifestações dos "imensos progressos" que estariam sendo feitos no ensino das línguas maternas. Em todos eles, o ensino tradicional da gramática para crianças estaria sendo criticado e, em alguns, estaria sendo recomendada a supressão de seu ensino no primário, reservando-o ao secundário. As noções gramaticais abstratas que ainda se ensinava no Brasil estariam fora do alcance da criança. Que aos pequenos fossem reservadas apenas as noções gramaticais concretas; os exemplos práticos.

Enquanto essa orientação se expandia entre europeus e norte-americanos, no Brasil, Barbosa se vê forçado a confessar "a rotina medra a seu salvo, affagada, applaudida, beneficiada pelas autoridades de ensino" (BARBOSA, 1883, p. 172). O corpo de tal delito é Grammatyca analytica... que "com todos os seus cunhos e apaganios da aprovação oficial" estaria correndo "pelas mãos das creanças, de escola em escola" (BARBOSA, 1883, p. 172).

\footnotetext{
${ }^{3}$ M. Bréal é de longe o autor mais citado. Somados os parágrafos quarto e quinto, ele aparece em 26 notas, sem considerar as vezes em que é mencionado apenas no corpo do Parecer. A ele será dedicado outro artigo. 
Em nota, Barbosa informa ter consultado a $4^{a}$ edição dessa gramática, e apesar da grande fama de que gozavam José Ortiz e Candido Matheus de Faria Pardal, para além dos círculos mais próximos aos assuntos educacionais, seus nomes ficam de fora do Parecer.

Estudos dão conta do sucesso que Ortiz e Pardal teriam obtido em suas respectivas carreiras docentes, realizadas não só contemporaneamente, como muito próximas geograficamente, embora nada prenunciasse essa aproximação no início das suas vidas adultas.

José Ortiz nasceu na Província do Rio Grande do Sul - em data desconhecida - e faleceu no Rio de Janeiro em 1880; Doutorou-se em Medicina pela Universidade de Paris e foi Membro do Instituto Histórico de França; ex-lente do Colégio do Padre S. Thiago, no Rio de Janeiro. Lecionou primeiras letras na Vila de Itapemirim, Espírito Santo, onde fundou e dirigiu um colégio; Lente de Francês, História e Geografia no Liceu de Vitória; Professor da Escola Normal de Vitória; posteriormente Professor do Liceu Niterói no Rio de Janeiro; professor livre de línguas e filosofia e autor de livros didáticos ${ }^{4}$ (BLAKE, 1899; PIROLA, 2013).

Candido Matheus de Faria Pardal nasceu no Rio de Janeiro, em 1818, e ali faleceu em 1888. Lecionou em diversos tipos de escolas; respondeu por diferentes matérias no ensino primário, secundário e profissional. Lemos (2006) destaca a docência de Desenho no Externato do Imperial Colégio de Pedro II desde 1864, além de ter lecionado no primário na Freguezia de Santa Rita. Uma vez aposentado dessas funções, dirigiu as escolas da municipalidade e escreveu livros para uso em escolas. Há registro também de intensa atuação associativa entre as décadas de 1870 e 1880, incluída a assinatura do Manifesto dos Professores da Corte de $1871^{5}$; atuação nas Conferências Pedagógicas ${ }^{6}$; participação em órgãos superiores da instrução publica, dentre os quais, membro do Conselho Diretor da Inspetoria Geral da Instrução Primária e Secundária da Corte, além de muitas outras atuações em diferentes frentes sociais e políticas (BLAKE, 1899; LEMOS, 2006; BORGES, 2014).

A parceria de Ortiz e Pardal na Grammática analytica... teria sido antecedidapela obra publicada em 1862, Novo systema de estudar a grammatica portugueza por meio da memoria, inteligência e analyse, ajudando-se mutuamente, lançado pela Typ. de Pedro Antonio D’Azeredo, Vitória - mas há controvérsias a respeito dessa dupla autoria ${ }^{7}$.

Grammatyca analytica... foi publicada pela primeira vez em 1871, no Rio de Janeiro, pela Typ. Universal Laemmert. Em 1872, em sessão ordinária do dia 3 de agosto, o Conselho Diretor da Inspetoria Geral da Instrução Primária e Secundária da Corte ocupou-se do "juízo crítico" dos examinadores de Grammática analytica..., de modo a apontar "os ligeiros defeitos que em geral reconhecia haver no

\footnotetext{
${ }^{4}$ Embora nas biografias de Ortiz e de Pardal se afirme que ambos eram autores de "livros didáticos", foram encontrados além de Grammatica analytica... apenas dois outros títulos: Novo systema de estudar a grammatica portugueza por meio da memoria, inteligência e analyse, ajudando-se mutuamente, cuja autoria será comentada mais adiante; e de Candido Pardal e Luiz Antonio Vieira de Barros e Vasconcellos, Novo silabário.

5 “O complexo quadro da instrução primária [no Município da Corte] foi denunciado em 1871, pelo Manifesto dos Professores Públicos da Instrução Primária da Corte endereçado ao Imperador e ao Ministro do Império, no qual apontaram a situação precária em que trabalhavam, acusando o governo de prejudicar o combate à ignorância e requerendo o reconhecimento do papel do magistério na obra da civilização. Em 1872, em meio a esta movimentação, pretendendo conhecer e controlar o movimento do magistério, o governo organizou as instruções especiais para regular a execução das Conferências Pedagógicas" (BORGES, 2008, p. 102). Candido Pardal foi um dos seus signatários. Outros autores examinaram o referido Manifesto e a participação de Pardal na sua elaboração, tais como Martinez (1998), acima referido; Lemos (2006; 2011); Borges (2014) Teixeira (2016).

${ }^{6}$ As conferências pedagógicas foram previstas pelo Decreto n. 1331, art. 76, de 17 de fevereiro de 1854, da chamada Reforma Couto Ferraz destinada à instrução primária e secundária do Município da Corte. No entanto, foram realizadas somente em 1872, cujo Regulamento da mesma data estabelecia que: “todos os professores públicos das escolas primárias do Município da Corte, serão convocados com oito dias de antecedência pela Inspetoria Geral da Instrução Pública, para se reunirem nas férias de Páscoa e nas do mês de dezembro, a fim de conferenciarem sobre todos os pontos que interessarem: regime interno das escolas; métodos de ensino; sistema de recompensas e punições para os alunos, expondo as observações que hajam colhido de sua prática e das leituras das obras que tenham consultado" (BASTOS, 2003, p. 2). Os autores citados na nota anterior também examinam as conferenciam pedagógicas realizadas no Rio de Janeiro em 1873.

${ }^{7}$ A autoria desse livro de 1862 é registrada de dois modos; alguns trabalhos apresentam Ortiz e Pardal como coautores e outros indicam Ortiz como único autor. Exemplo da proposição de coautoria encontra-se em Castilho (1962) e Polachini (2013; 2018). Na tese de Pirola (2013, p. 107), consta a fotografia da capa do livro de 1862 e nela Ortiz aparece sozinho. Pirola (2013) e Polachini (2018) fazem análises detalhadas desse livro.
} 
compêndio, a fim de ser delles expurgado, quando impresso para uso dos alumnos das escolas publicas primarias." (BRASIL, 1872, p. 62).

Após notificar os autores da necessidade desses ajustes e tendo eles aceitado adequar a referida gramática, em sessão do dia 24 de setembro de 1872, o Conselho Diretor da Inspetoria Geral da Instrução Primária e Secundária da Corte efetivou a aprovação da gramática de Ortiz e Pardal, com a determinação de que ela substituísse a gramática de autoria de Cyrillo Dilermando da Silveira (BRASIL, 1872). Em vista desse processo, Grammática analytica... teve sua $2^{a}$ edição revista publicada em 1873, pela Livraria Nicolau Alves, passando a ser imediatamente fornecida nessa reedição para as escolas primárias elementares da Corte mediante contrato celebrado entre a Inspetoria Geral da Instrução Primária e Secundária da Corte e os autores. Após a $2^{a}$ edição, foram publicadas: em 1876, a $3^{\mathrm{a}}$ edição; em 1884, a $5^{a}$ edição; e em 1888, a $6^{\text {a }}$ edição, todas pela Nicolau Alves/Alves e Cia Editores e todas com reformulações e ampliações ${ }^{8}$.

Impressa em capa dura, formato pequeno, com variação de páginas entre 100 e 150, conforme a edição, Grammática analytica... parte da definição de que a gramática é a "arte de fallar e escrever corretamente", subdividindo o estudo dessa "arte" em quatro partes: "etymologia"; "syntaxe"; "ortographia"; e "prosódia".

Na primeira parte, no estudo da "etymologia", enfoca-se o conhecimento e a classificação das palavras, definida essa última como "expressão de uma idéa, representada aos ouvidos por um ou mais sons, e aos olhos por uma ou mais letras, formando syllabas" (ORTIZ; PARDAL, 1884, p. 3) ${ }^{9}$.

Ao classificar as palavras quanto à sua formação - primitivas ou derivadas por afixos -, esclarece-se que elas podem ser dividas quanto à sua natureza em dez "espécies" ou "partes da oração", a saber: "o substantivo ou o nome, o artigo, o adjectivo, o pronome, o verbo, o particípio, o advérbio, a preposição, a conjuncção e a interjeição." (ORTIZ; PARDAL, 1884, p. 4). Os seis primeiros tipos são classificados como variáveis, pois "mudam a sua terminação", e os quatro tipos finais como invariáveis, "pois nunca mudam de terminação".

Mediante essa explicação, são apresentadas as definições, características, variações (apenas para as variáveis), propriedades e formas de classificação de cada um dos "tipos de palavras", esclarecendo-se as regras gerais para se compreendê-los. Ao término dessa explanação, que ocupa a maior parte do compêndio (cerca de 3/4 do impresso), são apresentados 28 exercícios de "analyse gramatical" e "analyse logica", os quais indicam processo progressivo de complexidade quando às possibilidades de construção das orações em função dos tipos de verbos - "substantivos", "virtuaes", "impessoaes" ou "unipessoaes"-.

A "analyse grammatical" consiste na identificação de cada tipo de palavra utilizada em uma dada oração, portanto, corresponde à classificação delas em relação ao seu valor gramatical. A "analyse logica" consiste na definição das palavras quanto à função que exercem no âmbito da oração, voltandose à identificação de sujeito, verbo, atributos e complementos.

Ainda com relação aos exercícios de "analyse grammatical e logica", cumpre destacar que as orações utilizadas apresentam conotação moral e religiosa, em consonância como o modelo de ensino primário elementar estabelecido desde 1854. São analisadas frases, tais como: "Deus é justo"; "Glorificarse de uma falta é aggraval-a"; "Caim matou Abel ou a Abel"; "Comei com Moderação"; "Arrependo-me do pecado"; "Pedro é o mais modesto dos homens". Assim, associado ao ensino gramatical, faz-se um tipo de reforço de ensinamentos voltados à formação moral e religiosa cristã, com referência direta a conteúdos bíblicos.

Após a exposição dos exercícios de "etymologia", inicia-se a segunda parte do compêndio de Ortiz e Pardal, essa destinada à "syntaxe".

A "syntaxe" é definida como "parte da Grammatica que ensina a compor a oração e o período grammatical", sendo esse período compreendido como "a reunião de palavras que formarão uma ou mais de uma oração tendo sentido perfeito e terminado por ponto." (ORTIZ; PARDAL, 1884, p. 107). No estudo da "syntaxe" são exploradas as orações de período simples e período composto, de

\footnotetext{
${ }^{8}$ Não foram localizadas informações sobre a $4^{a}$ edição.

${ }^{9}$ Como não foi possível o acesso à $1^{\text {a }}$ edição, foi consultada a mais antiga localizada: $5^{\text {a }}$ edição, de 1884 . Educação em Revista|Belo Horizonte|v.37|e26782|2021
} 
modo a proceder à definição e caracterização de cada uma delas. Em vista disso, são apresentados os conceitos de "sujeito", "complemento", "attributo", "apposto" e "vocativo". Também são expostos elementos de concordância e regência "natural" e "figurada", bem como vícios de linguagem. Em seguida aos conceitos de "syntaxe", são apresentados alguns modelos de "analyse syntaxica e logica.

Na terceira parte, relativa à "orthographia", desenvolve-se a parte da gramática que se destina a ensinar a escrever as palavras, fazendo uso correto das letras, sinais de pontuação e acentos. Em vista disso, são apresentadas as regras ortográficas, regras de uso das letras maiúsculas, regras de separação de sílabas, figuras de dicção, uso das pontuações e dos acentos.

$\mathrm{Na}$ quarta e última parte, aborda-se a "prosódia", definida como "parte da gramática que ensina a bem pronunciar as palavras." Para isso, são explorados aspectos relativos ao valor sonoro das sílabas, de modo a ensinar a contagem e identificação do valor que elas têm em textos poéticos.

Com esse conteúdo, Grammática analytica ... é finalizada, sem apresentar exercícios específicos para as duas últimas partes. Constam apenas alguns exemplos em referência aos conceitos explorados sobre "orthographia" e "prosódia". Da edição consultada, e o mesmo deve se dar nas demais, não aparece qualquer ilustração.

Pelo exposto, nada indica, portanto, que a Grammatica analytica... apresentasse alguma inovação significativa em comparação às gramáticas que vinham sendo adotadas. Estava longe de incorporar preceitos centrais que então caracterizavam, no Brasil, os primeiros passos rumo ao método de raiz pestalozziana, o intuitivo, e sua expressão analítica no âmbito dos saberes elementares - ler, escrever e contar ${ }^{10}$. Quiçá, nem mesmo em relação à preterida gramática de Cyrillo Dilermando da Silveira, substituída provavelmente por estar ele já falecido à época e não ter um seu representante a defendê-lo ${ }^{11}$. Em contrapartida, Ortiz e Pardal gozavam de prestígio político e social. No caso de Pardal se tratava mais do que prestígio, uma vez que desempenhava funções de poder que lhe permitiam decidir sobre quais compêndios as escolas deveriam utilizar no Município da Corte.

Tendo sido adotada antes mesmo da sua aprovação pelo Conselho Diretor da Inspetoria Geral da Instrução Primária e Secundária da Corte, a Grammatica analytica recebeu uma precoce avaliação sobre seu ajustamento e aceitabilidade e para o ensino primário elementar da Corte durante as Conferencias Pedagógicas realizadas em 1873 (BRASIL, 1873). No entanto, no relatório sobre "Compendios e Materiais do Ensino", de Antonio Felix Martins, Inspetor Geral da Instrucção Primaria e Secundaria do Municipio da Corte, elaborado ao final de 1872 e apresentado ao Conselheiro Inspetor Geral da Instrução Primária e Secundária em 1874, registra-se outra avaliação.

Ao se explicar a importância de verificação do cumprimento da legislação vigente sobre o uso de livros e compêndios na Corte, consta nesse relatório a informação de que o compêndio de Ortiz e Pardal, conforme também destaca Teixeira (2008), foi alvo de reclamação por parte dos professores, por se entender que ele era demasiado extenso:

O compendio adoptado é o dos professores Dr. Ortiz e Pardal. Parte do professorado primário pronuncia-se contra o livro, entendendo que é por demais extenso e que deve ficar reservado para a $7^{\mathrm{a}}$ e $8^{\mathrm{a}}$ classes, preferindo para as inferiores as grammaticas de Cyrillo e de Polycarpo. (MARTINS, 1874, p. 49).

Nesse contexto, no que tange especificamente ao ensino da gramática, a comissão asseverou em seu relatório que esse tem constituído "estudo mais repulsivo", quando deveria ser dos mais “animados e agradáveis" (MARTINS, 1874, p. 43). Assim, embora o ensino da gramática fosse entendido

\footnotetext{
${ }^{10}$ Valente (2015), examinando métodos de ensino da Matemática no curso primário de 1890-1930, verificou duas variantes do método intuitivo: o intuitivo-sintético e o intuitivo-analítico. Cabe verificá-las em relação ao ensino da leitura e da escrita. 11 “Cirilo (Cyrillo) Dilermando da Silveira - Nasceu em Icó, filho de Manoel Dilermando Paz. Funcionário da Tesouraria Provincial. Professor nas províncias do Espírito Santo e Rio de Janeiro. Fundou um colégio em Valença (RJ). Serviu na Recebedoria do Município Neutro. Publicou: Coleção de traslados oferecidos para uso da mocidade brasileira; Compêndio de gramática da língua portuguesa da primeira idade (1855; obra adotada pelo Conselho da Instrução Pública); Exercícios de análise lexicográfica on gramatical e de análise sintáxica ou lógica (1970). Morreu no Rio de Janeiro”. Acesso em 24/11/2020:

http: $/$ portal.ceara.pro.br/index.php?option $=$ com_content\&view $=$ article\&id=1864\&catid=293\&Itemid=101 $>$.
} 
como um dos mais concorrentes para o desenvolvimento da inteligência, a comissão avaliou que a escola o fazia puramente com a memorização de definições e regras, sem explicações que rompessem com a "monotonia da esteril recitação". Completa a comissão em seu relatório que: "Estudar assim não é aprender, accumular preceitos sem apllicação é sobrecarregar a memoria sem proveito algum. Esse estudo carece de completa reforma, principalmente nas escolas de meninas onde, por assim dizer, não existe." (MARTINS, 1874, p. 43).

Em face desses aspectos, a comissão avaliou que muito dessa inadequação do ensino da gramática tinha relação com as diferentes normativas relacionadas a essa matéria, uma vez que o decreto de 1854 estabelecera ensino limitado às "noções essenciais"; o regimento interno das escolas fixara a "analyse grammatical" e a tabela de distribuição de matérias indicara a "analyse logica e grammatical" (MARTINS, 1874, p. 43). Em vista dessa "confusão", a comissão posicionou-se favorável ao disposto no decreto de 1854, entendendo que:

A escola elementar não tem por missão ensinar e devassar as difficuldades grammaticaes; seu objeto limita-se a fazer fallar os meninos, com á devida correcção, o que se obtem, não por meio de analyses e de regras complicadas, mas por meios práticos, e definições e regras simples, que os meninos, sendo bem dirigidos, chegarão a descobrir e a formular, por si mesmos. (MARTINS, 1874, p. 44).

Para concluir, a comissão apresentou recomendações de como deveria ser conduzido o ensino da gramática em todas as escolas da Corte, enfatizando que a sua base deveria ser a leitura, como forma de enfocar o estudo das "partes do discurso":

A leitura póde servir de base para o estudo da grammatica: lido um trecho, depois de devidamente explicado, o professor chamará a attenção dos alumnos para as diversas partes do discurso, contidas nesse trecho, e mostrará a funcção de cada uma; depois fará a applicação que a sua experiencia e saber lhe indicarem, e terminará a lição fazendo co que os alumnos exponham, um por um, o assumpto que acabaram de ler, aproveitando então para corrigir-lhes os defeitos de dicção, de grammatica, e de construcção, que tiverem commettido. (MARTINS, 1874, p. 44).

Jornais também acolheram críticas à Grammatica analytica... de Ortiz e Pardal. A Província órgão do Partido Liberal, de Recife, reservou espaço entre julho e agosto de 1874, em quatro edições, para as críticas de Albino de Meira à gramática. Segundo Borges (2014) ${ }^{12}$, Albino de Meira era professor de "língua nacional" em prestigiosa escola pública da capital de Pernambuco. Suas críticas se iniciam com o princípio pelo qual Ortiz e Pardal conduzem suas lições:.

Gramática, dizem Ss. Ss. é a arte de falar e escrever corretamente. Essa definição é má, porque restringe sobremodo o objeto definido, reduzindo a gramática a sua prática, a uma grosseira materialidade, despojando-se de seu lado filosófico e científico [...] (MEIRA apud BORGES, 2014, p. 263).

Borges (2014) completa à mesma página:

Essa primeira frase foi suficiente para render assunto para todo o primeiro artigo de Albino de Meira que ocupou três colunas do periódico. O professor também proferiu severas críticas ao método usado para abordar os temas e as definições apresentadas, comentando cada discordância minuciosamente, bem como fazendo condenações indiretas à inspetoria que aprovou a gramática. Albino apresenta, sobretudo, questões relativas à forma de conceituar que considera imprecisa, superficial ou incompleta (BORGES, 2014, p. 263).

Apesar das críticas, a Grammatica analytica... permaneceu em uso pelo menos até o final da década de 1880, quando sua $6^{a}$ edição revista e aumentada foi publicada com a chancela: "Adoptado pela

\footnotetext{
12 Borges (2014) rastreou notícias a respeito de Pardal em 400 periódicos oitocentistas digitalizados pela Hemeroteca da Biblioteca Nacional, cobrindo o período de 1837 a 1893. Neles foram encontradas críticas, elogios, recomendações, propagandas, além de sátiras a Pardal e a seu gramatiquês.
} 
inspetoria geral da instrucção publica, com approvação do governo imperial, para compendio das escolas primarias" do Município da Corte ${ }^{13}$.

Assim, as críticas de Ruy Barbosa à gramática em questão foram antecedidas dessas e de tantas outras espalhadas em documentos oficiais e na imprensa de ampla circulação. $\mathrm{Na}$ análise de Barbosa sobre a necessidade de reforma do ensino da língua na Corte em face dos "imensos progressos" advindos da orientação intuitiva no final do século XIX, esse autor destaca que se identificava nas escolas do Rio de Janeiro situação de vergonha, "aplaudida", "beneficiada" e "afagada" pelas autoridades.

O corpo desse "delito", segundo ele, se encontrava no uso da Grammatica analytica ..., uma vez que esse livro, ao cometer o "velho pecado" de associar a gramática à arte de falar e escrever bem, o fazia mediante traço característico da "antiga pedagogia", qual seja: a desvinculação entre realidade e as formas corretas do dizer e do escrever.

Explica Barbosa que a gramática de Ortiz e Pardal tinha como pressuposto um ensino pautado na definição de regras e conceitos em forma de síntese, de modo a "desviar" o estudo da língua dos fatos que constituíam a sua trama. Para ele, esse livro desconsiderava a "origem absoluta" de toda gramática, tornando o seu estudo atividade "extrínseca", "formalista" e "convencional" de textos já consagrados.

Assevera Barbosa que, à época, a filologia moderna se "profligava" contra essa tendência, abstendo-se das preocupações "errôneas" e do modo "inútil" de entender a gramática como "arte" de escrever e falar bem. Por essa razão, ao analisar o modo como Grammatica analytica... sistematizava seus conteúdos, Barbosa a caracteriza como uma "grosa" de "locuções enigmáticas", que "entontece" e "abafa" o espírito infantil. Para ele, essa gramática produzia uma "tirania radical" contra a inteligência infantil, que resultava em "apatia mental", "imbecialidade" e "cretinismo" para as novas gerações.

Somado a esses aspectos, Ruy Barbosa complementa que a gramática de Ortiz e Pardal era repleta de "lastimosos syntomas" de uma "infeliz" preocupação "metaphysica", centrada em classificações "monótonas" e "imprestáveis", indicativas de operações gramaticais sem qualquer utilidade ou sentido para uma criança. Com isso, conclui o então deputado que Grammatica analytica... consistia em um:

[...] palhiço inútil que se trabalha por fartar a intelligencia do menino, submettido por esta inepta pedagogia a um regimen syntematico de fadiga mental, atravez de um urzedo inextricável de regras e enumerações, que o espírito rejeitará de si com aversão, apenas a edade o liberte das violências da escola. (BARBOSA, 1883, p. 175).

\section{UM EXEMPLAR DO MÉTODO INTUITIVO: ILLUSTRATED LESSONS IN OUR LENGUAGE..., DE QUACKENBOS}

Uma vez expostos os equívocos da gramática de Ortiz e Pardal, o "precioso livrinho" de Quackenbos, Illustrated lessons in our lenguage; or how to speak and write correctly. Designed to teach english grammar, without technicalities, é apresentado por Ruy Barbosa como exemplo eloquente da utilização da intuição como base essencial de todo o ensino.

É exercendo a linguagem, que se preparará, para deduzir ele mesmo [o aluno] a teoria das suas leis. $\mathrm{Da}$ aplicação desse processo temos diante de nós um exemplo nas lições ilustrativas de linguagem, por Quackembos [sic], destinadas a ensinarem a gramática pelo método objetivo [nota para as Illustrated lessons...]. Este precioso livrinho americano evita "a formidável legião de inflexões e conjugações [nota para citar longamente B. Berger, L'enseignement ...], divisões e subdivisões e exceções [nota para uma também longa citação de M. Bréal, Mélanges de...] que

\footnotetext{
13 Borges (2014) encontrou nos periódicos examinados 480 referências a Pardal; poucas mencionam Gramnatica analytica... e sua adoção em outras províncias: em São Paulo consta que era adotada no Colégio de Nossa Senhora Mãe dos Homens e no Externato dos Aprendizes de São João de Ypanema (Correio Paulistano, 11/06/1878) e em Goiás na Escola Normal (Correio Oficial de Goyaz, 3/5/1884). Foram encontradas referências à gramática de Ortiz e Pardal nos catálogos de livrarias em Minas Gerais, Mato Grosso, Ceará e duas do Rio de Janeiro, entre 1876 e 1889, o que sugere ter se manifestado demanda pelo título nesses locais.
} 
d'antes se reputava indispensável, e procura constantemente, desde o começo, familiarizar o discípulo com o uso da linguagem como realidade quotidiana de primeira importância, não como composto de abstrações teóricas; substitui a árida rotina da regência verbal, com o seu interminável círculo de definições e regras, por uma série de exercícios orais e escritos, ensinando indutivamente a arte de exprimir o pensamento, e desenvolve substancialmente o curso inteiro mediante simples lições de coisas" [nota para Illustrated lessons..., p. 3] (BARBOSA, 1883, p. 176).

A edição citada por Barbosa (1883) do Illustrated lessons ... é de 1880, mas o seu lançamento se deu em 1876. O "livrinho" obteve oito edições até 1888 pela D. Appleton \& Company que editou praticamente todos os livros de G. P. Quackenbos ${ }^{14}$.

George Payn Quackenbos nasceu em 1826, em Nova York, e faleceu em 1881, na mesma cidade. Obteve o diploma de Bacharel, em 1843, e de Mestre, em 1864, pelo Columbia College. Lecionou no Collegiate School na Cidade de Nova York. Criou uma escola. Obteve o título de Doutor em Direito, em 1863, pela Wesleyan University. Até 1868, manteve atividades docentes. Ao longo da vida profissional contribuiu para várias revistas acadêmicas e por dois anos (1848-1850) editou a revista Literary American. Ganhou notoriedade como autor de livros de natureza diversa, principalmente didáticos, incluindo gramática, história, retórica, filosofia natural e série de aritmética ${ }^{15}$ (THE UNITED STATES BUREAU OF EDUCATION, 1900; WELSCH, 1994).

Quando Illustrated lessons... foi lançado, Quackenbos já tinha publicado 16 outros títulos didáticos, além de uma noveleta - como ele denomina o livrinho de "crime e mistério" (1846) -, um livro de contos (1855) e um poema (1872). Seu nome também já circulava fora dos Estados Unidos, como atesta a publicação, em 1874, por uma editora de Atenas, de História dos Estados Unidos da América. Publicou, posteriormente, mais três didáticos, além das reedições/reeimpressões ${ }^{16}$ que seguiram por anos e as novas publicações em língua estrangeira, como ocorreu com História dos Estados Unidos, publicado aproximadamente em 1888 por uma editora de Tóquio ${ }^{17}$.

Illustrated lessons..., o último livro didático do autor sobre o assunto, dessa feita para crianças, foi antecedido por cinco didáticos de composição, retórica e gramática, além de um dicionário de pronúncia de inglês e francês ${ }^{18}$, destinados aos estudantes do High School e dos Colleges. Ao longo do tempo, publicou também, em inglês, seis didáticos de história - além das traduções já referidas; um de história natural - com circulação internacional - e seis de aritmética.

Excetuadas as ilustrações - centrais no método intuitivo tal como difundido nos Estados Unidos - não se encontram no Illustrated lessons... características inovadoras que já não estivessem presentes nos seus cinco livros anteriores relativos à composição, gramática e retórica. Foram os dois primeiros - First lessons in composition, in which the principles of the art are developed in connection with the principles of grammar; embracing full directions on the subject of punctuation; with copious exercises (1851) e Advanced course of composition and rhetoric: a series of practial lessons on the origin, history, and peculiarities of the English language... Adapted to self-instruction, and the use of schools and colleges (1854/1864) - que produziram maiores impactos refletidos imediatamente na vasta adoção em escolas e Colleges e, consequentemente, em reedições subsequentes. As suas repercussões mediatas se aferem pelos muitos trabalhos acadêmicos dedicados a analisá-los até

\footnotetext{
${ }^{14}$ Em 2016, o livro foi reeditado como "clássico" pela Wentworth Press.

${ }^{15}$ Nas raras biografias de Quackenbos, consta que os seus livros de Aritmética "foram preparados tendo como base os trabalhos de George R. Perkins [...], Doutor em Direito, e publicados pela [...] D. Appleton \& Co, de Nova York" (THE UNITED STATES BUREAU OF EDUCATION, 1900, p. 787). No sitio The Online Book Page há uma lista quase completa dos títulos publicados por Quackenbos, bem como suas reedições. Há reedições atuais de alguns dos seus livros, especialmente de Aritmética. No Japão ele continua em circulação com publicações para essa disciplina.

${ }^{16}$ Nas edições dos EUA não é fácil discriminar a reedição da reimpressão.

${ }^{17}$ Há muitas referências à circulação dos livros didáticos de GPQ no Japão (NISHIHIRA, 1972; HANE, 1957).

${ }^{18}$ De todos os títulos de destinação escolar, ou que foram, com o tempo, adotados nas escolas, nenhum superou em reedições o dicionário, em coautoria de A. Spiers e Gabriel Surm, Spiers and Surenne's French and English pronouncing dictionary: newly composed from the French dictionaries of the French Academy, Laveaux, Boiste, Bescherelle, Landais, etc., and from the English dictionaries of Johnson, Webster, Worcester, Richardson, etc. lançado aproximadamente em 1852 e republicado continuamente ao menos até 1912. Foram encontradas edições posteriores, mas em descontinuidade. 
os presentes dias ${ }^{19}$. Como os dois primeiros livros acima referidos, o livro de 1876 obteve muitas reedições - segundo Schultz (1999), foram 40 -, mas, diferentemente daqueles, o Illustrated lessons... obteve até o momento pouca atenção dos estudiosos.

No Prefácio, de 1876, o autor apresenta Illustrated lessons... como "resultado de um esforço sério de ensinar crianças pequenas" (QUACKENBOS, 1876, p. 3). Crianças pequenas, mas não iniciantes. O público a que se dedica esse livrinho é de crianças que, em princípio, já sabiam ler e escrever. Ou seja, não é um "primer" ou um "speller". Compõe-se de 90 lições, em média de duas páginas cada. Apesar do título do livro, apenas 12 lições são ilustradas. As lições são sempre acompanhadas de exercícios. Ao final do livrinho, um índice alfabético completo dos assuntos tratados, que, segundo o autor, dispensaria um sumário.

O objetivo central do autor é ensinar o aluno "de maneira natural e de bom senso", de uma forma inteligente e prática, a falar e escrever corretamente segundo os princípios da gramática inglesa, mas eliminando suas "tecnicalidades". Por isso, deixa de lado as intermináveis "inflexões e conjugações, divisões e subdivisões, observações e exceções", procurando desde o início "familiarizar o aprendiz com o uso da linguagem como uma realidade cotidiana de fundamental importância - não como mera abstração teórica". Com esse propósito em mente, garante o autor ainda no Prefácio, substituir "a rotina seca da análise verbal, com sua infinita rodada de definições e regras, uma variedade de exercícios orais e escritos ensinando a arte da expressão de forma indutiva" (QUACKENBOS, 1876, p.3).

Aí está uma chave para o entendimento da proposta de Quackenbos: o uso da indução como princípio lógico do método de ensino. Por outro lado, propõe "acabar com o aprendizado mecânico e tornar a aula de linguagem um veículo de valiosa disciplina mental” (QUACKENBOS, 1876, p.3).

Quanto à adesão ao ensino indutivo, Quackenbos logo dá nome ao método que adota: lições de coisas [Object-lessons]. Portanto, para ele, no seu método conjugam-se indução e intuição. O livrinho oferece os "modelos corretos"; o professor os escreve no quadro-negro; os alunos pensam e discutem sobre eles. O professor cuida para que não desviem a atenção do essencial por meio de perguntas aos alunos, conduzidos, assim, a chegarem a suas próprias conclusões. Os exercícios se repetem de sorte a garantir a memorização. "Ilustrações pictóricas de novos desenhos feitos expressamente para o trabalho auxiliam nesse tratamento do objeto da matéria e se comprovarão [...] não menos úteis que atraentes" (QUACKENBOS, 1876, p. 3).

A ênfase nas ilustrações tanto quanto nos exercícios, extensos e variados, provam, segundo o autor, o seu interesse em tornar um estudo, de "proverbial secura", em uma atividade ao alcance do aluno e ao mesmo tempo agradável (QUACKENBOS, 1876, p. 3). Os exercícios desempenham, ainda, outra função: são eles que balizam a continuidade das etapas: a próxima lição só pode ser iniciada quando o texto anterior tiver sido perfeitamente entendido; nenhuma nova lição deve ser iniciada enquanto a anterior não tiver sido dominada.

Quackenbos oferece ainda um parâmetro para a posição do seu Illustrated lessons... no rol dos didáticos que começaram, à época, a ser vendidos em profusão nos Estados Unidos: não é parte de uma série; é um livro "completo em si"; tudo o que se precisa para o aprendizado da gramática está ali, considerando-se a quem se destina e um professor inteligente no seu manuseio. Tudo o que se precisa para o aprendizado da língua inglesa, "os principais princípios de bom estilo, críticas orais, correspondência comercial com diversas formas mercantis e, especialmente, os meios de garantir fluência de

\footnotetext{
19 Encontram-se também, mas em menor quantidade, estudos sobre os livros de história e de história da natural de Quackenbos (BECHTEL, 1968). Do Illustrated lessons... foram localizados muitos anúncios publicitários e resenhas. A título de ilustração: "O autor escreveu um livro muito simples para instruir as crianças de uma maneira muito simples no uso da linguagem. As lições são indutivas e progressivas e deixam de fora todas as formas de inflexões e conjugações, regras e exceções. Também poderia ter sido bom, talvez, ter colocado a regra, a afirmação, a inferência ou a conclusão no final de cada lição para o aluno memorizar, mas o autor, provavelmente se lembrando das dificuldades da memória de sua própria infância, foi adequado ao poupar horas cansativas e esforços inúteis para as crianças. Esperamos que ele não tenha cometido um erro no outro extremo. A memória deve ser exercitada e, se não for feita, um animal de carga fará à criança uma infinidade de bons serviços. A teoria deste livrinho é boa e, agora, se os professores práticos nos disserem seu valor na sala de aula, ouviremos com prazer o que eles têm a dizer." (NEW ENGLAND JOURNAL OF EDUCATION, Vol. 4, No. 5, p. 60, August 12, 1876). Schultz (1999) é um dos poucos autores que examina Illustrated lessons... entre os livros de Quackenbos relativos ao assunto.
} 
expressão, recebem atenção cuidadosa" (QUACKENBOS, 1876, p. 4. Itálico no original). Mas, ainda que se pretenda utilizá-lo em uma série,

essas lições serão uma introdução adequada, uma vez que abrangem um campo muito mais amplo do que o habitual nas gramáticas elementares e, lidando com nenhum ponto controverso, são adaptadas a qualquer sistema que o professor possa preferir. Acreditase que eles ensinarão mais gramática do que esses livros didáticos elementares, pelos quais são oferecidos como substitutos, e o façam de maneira mais completa e fácil (QUACKENBOS, 1876, p. 4).

Antes da primeira lição, Quackenbos introduz uma prévia, Lessons in Our Language, na qual estabelece conexões entre o pensamento, a palavra, a sentença, os meios de expressá-las - escritas e orais - e, por fim, exercícios. Essa preliminar não tem ilustração. Apesar de longa, a citação é necessária:

Todos nós sabemos conversar. Nós conversamos a fim de expressar algum Pensamento que está em nossas mentes.

Expressamos pensamentos com Palavras. Cada palavra significa alguma coisa. Ao juntar as palavras, podemos fazê-las expressar qualquer pensamento que desejamos.

Quando uma criança começa a falar, usa palavras isoladas. Mas logo aprende a juntar duas ou três palavras - depois mais -, assim, forma Sentenças.

Podemos formar frases sem falar uma palavra. Quando o Capitão John Smith foi feito prisioneiro pelos índios, logo depois que a Virgínia se estabeleceu, ele lhes disse que, se concordassem em libertá-lo, deveriam encontrar em um dia ou dois, em um determinado lugar na floresta, vários dos artigos que ele citou. Ao ir para lá na hora marcada, encontraram exatamente o que ele havia prometido; e tendo-o como um grande mágico, eles o deixaram ir.

Mas ele não era mágico. Ele não fez mais do que qualquer um de nós poderia fazer. Ele havia conseguido enviar uma carta aos amigos, contando o que havia prometido, e eles distribuíam as coisas por lá. Pensamento que ele não tinha falado com seus amigos, ele havia expressado seus pensamentos para eles. Os pensamentos, portanto, podem ser expressos tanto pela escrita quanto pela fala.

Quando falamos ou escrevemos nossos pensamentos, devemos usar as palavras corretamente. Como fazer isso, vamos aprender. (QUACKENBOS, 1876, p. 5. Grifos e itálicos no original)

Em seguida, as questões para orientar os exercícios:

Questões. - Por que as pessoas falam? Quando você aprendeu a falar? Como você aprendeu a falar? O que você usa para expressar seus pensamentos? Além de falar, qual outra maneira de expressar pensamentos?

De quais três letras a palavra escrita distante é composta? Dê o som de cada uma dessas letras. De quais três sons a palavra falada distante é composta? Do que é composta a palavra escrita? Do que é composta uma palavra falada? O que as letras representam? O que as palavras expressam? O que é composto de palavras? Você já ouviu frases usadas e quando? Você já leu frases e quando? O que vamos aprender? (QUACKENBOS, 1876, p. 6. Grifo no original)

Nas páginas seguintes, a lição 1 com ilustração (ocupa as páginas 6 e 7). Como as demais, essa não tem título. 


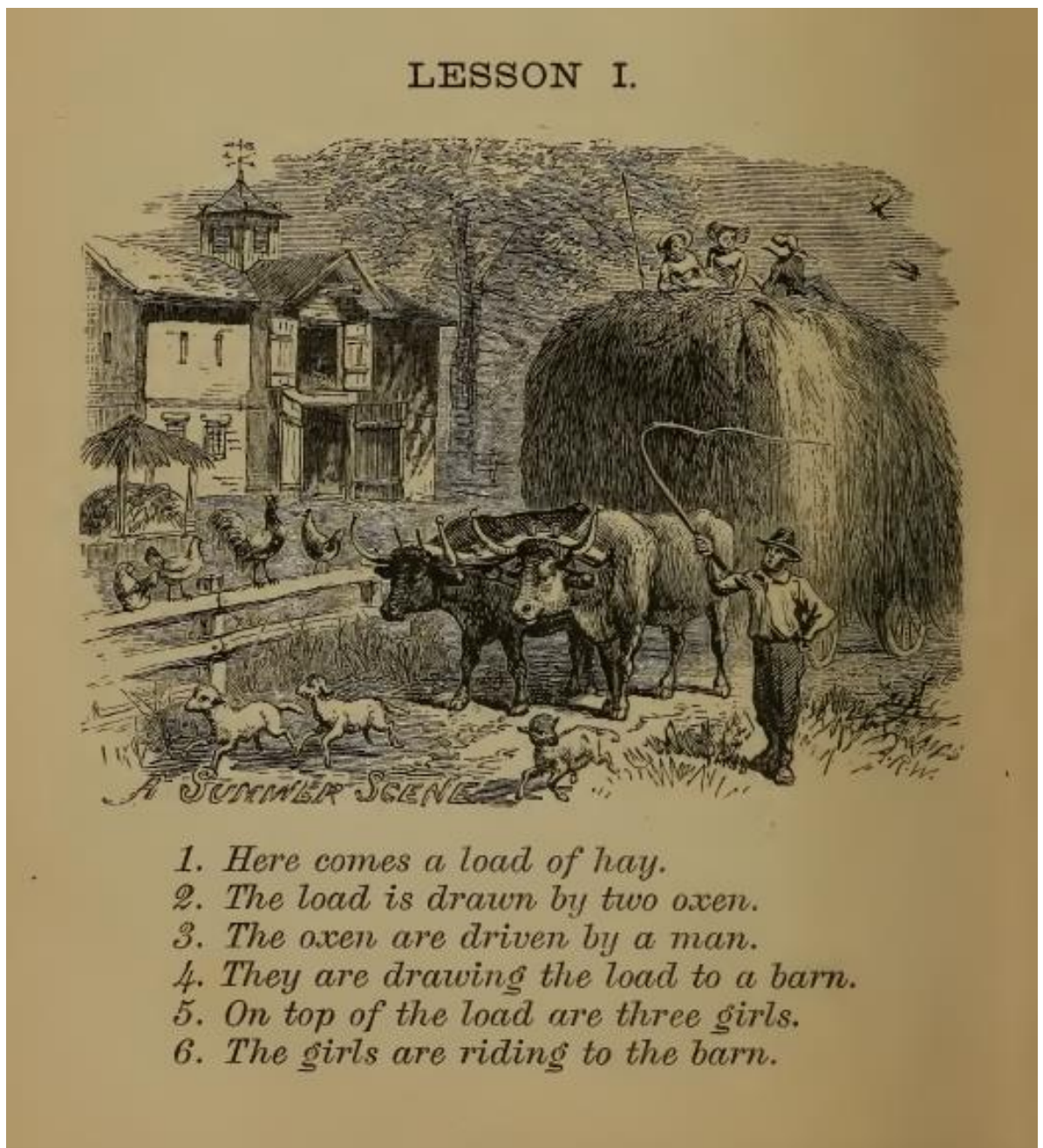

Figura única: Ilustração da Lição I do livro Illustrated lessons... de G. P. Quackenbos, 1876.

Fonte: Quackenbos, 1876, p. 6.

Indução e disciplina mental. Quackenbos adota o método que conduz os alunos a formularem um conceito, uma categoria, uma ideia geral a partir de casos particulares. O seu ponto de partida é a experiência, o "contato" com as coisas e a "relação" com as pessoas. Ele acata o entendimento de que a experiência não "entrega" ao intelecto fragmentos de realidade, mas a realidade já razoavelmente "codificada" pela intuição. Voltaremos a esse tópico logo adiante.

Quanto à disciplina mental, aparentemente, não se refere em sentido estrito à "teoria da disciplina mental" cuja raiz estaria no racionalismo dedutivista de Christian Wolff, que afirmava a mente como um conjunto de faculdades hierarquizadas. Apesar de não expor em detalhes o seu entendimento, tudo indica que para ele "disciplina mental" se refere especificamente a persistentes exercícios que poderiam aperfeiçoar habilidades como as da fala, do cálculo e, particularmente, da memória e da atenção. Esse, afinal, era o modo como, no cotidiano escolar, a maioria dos professores traduzia a referida teoria para o uso em sala de aula ${ }^{20}$.

Quackenbos não era racionalista nem dedutivista em sentidos estritos. Os estudos sobre ele como autor de livros didáticos de retórica, composição e gramática - resumidos posteriormente em uma única expressão: Inglês - situam-no na convergência de outras vertentes filosóficas. Quackenbos teria reunido em si tanto elementos da chamada "nova retórica" quanto elementos da pedagogia pestalozziana - que se expressam particularmente pela adesão às lições de coisas -. Essa síntese, Quackenbos teria

\footnotetext{
${ }^{20}$ Essa compreensão da "disciplina mental” a que se refere Quackenbos pode ser refinada nos seus trabalhos anteriores nos quais é mais explícito a respeito do assunto (WELSCH, 1994). 
realizado de modo peculiar, pode-se dizer inovador, e teria, assim, aberto o caminho para outros didáticos dessas e de outras matérias pautados na mesma metodologia.

A Encyclopedia of Rhetoric and Composition confirma a filiação de Quackenbos à Nova Retórica ${ }^{21}$, particularmente a George Campbell.

Como educador e autor de obras educacionais com destaque para composição, retórica e gramática, Quackenbos teria se destacado pela capacidade manifestada em meados do século XIX de oferecer aplicações mais práticas de ideias altamente teóricas, mas amplamente divulgadas da New Rhetoric [...] Enquanto muitos de seus contemporâneos se esforçavam para criar versões americanas dessas importações altamente influentes da Grã-Bretanha, Quackenbos sintetizou as características mais proeminentes da New Rhetoric, apresentando-as em termos decididamente práticos. O resultado - o Advanced Course of Composition and Rhetoric (publicado originalmente em 1854) - foi uma retórica que abordava o processo de composição com base na psicologia da faculdade de Campbell e, ao fazê-lo, tratou o processo de invenção como composto principalmente de seleção e "pensamento cuidadoso, deliberado e concentrado".

Quackenbos estava entre os primeiros autores de livros didáticos de composição a atenuar o processo de seleção fornecendo listas de assuntos (tópicos) para composição. A noção de "pensamento" de Quackenbos demonstra mais claramente a epistemologia da New Rhetoric pela maneira que parece ser apenas um filtro para o fenômeno: "Esta é uma análise do assunto, ou um desenho das várias cabeças que se sugerem à mente como apropriadas ao tema do discurso". Quackenbos sinalizou a natureza prática de seu livro ao incluir uma seção exaustiva sobre gramática, um assunto tipicamente ignorado nos tratados mais abstratos sobre retórica. Ao mesmo tempo, ele acenou na direção de Hugh Blair e da tradição beletrista ao incluir longas discussões sobre gosto, sublime e prosódia.

Alguns estudiosos sugeriram que Quackenbos foi o criador dos modos de discurso (descrição, narração, exposições, argumentação), enquanto outros sustentam que essa distinção pertence a Alexander Bain, Henry Day ou Samuel Newman. Independentemente de quem justamente merece crédito (ou culpa) pelo desenvolvimento de uma abordagem pedagógica tão influente, parece justo propor que Quackenbos certamente foi um dos primeiros a fazer dos modos uma parte integrante da pedagogia da composição (ENOS, 2011, p. 579). ${ }^{22}$.

O débito de Quackenbos com a "psicologia" e a retórica de Campbell é aceito por outros estudiosos do assunto ${ }^{23}$. George Campbell é um dos nomes destacados do chamado Iluminismo Escocês que, embora tenha se espraiado, teve poucos epicentros além de Edimburgo e Aberdeen; um movimento do século XVIII, como o ocorrido em outros países europeus, embora a Escócia, além de isolada, fosse pobre e atravessada por conflitos políticos e religiosos, direta ou indiretamente decorrentes da sua relação com a Inglaterra ${ }^{24}$. Ao contrário do ocorrido em outros países europeus, o iluminismo escocês não foi antirreligioso ou particularmente anticristão. A igreja escocesa liderada por clérigos como Campbell e Blair contribuiu significativamente para o "enlightenment" ${ }^{25}$ naquele país; os dois presbiterianos

\footnotetext{
${ }^{21}$ Os artigos de Thomas O. Sloane e Chaim Perelman, na Encyclopedia Britannica, não se referem à geração de Campbell, Whately e Blair como representante da Nova Retórica; essa nomenclatura é reservada a um movimento posterior, no qual se destacam, de pronto, o próprio C. Perelman e Kenneth Burke. Disponível em: < https://www.britannica.com/topic/rhetoric/The-Renaissance-and-after>, Acesso em: 10/08/2020.

${ }^{22}$ Escócia se uniu à Inglaterra em 1707 e pôs fim ao seu parlamento autônomo. George Campbell (Aberdeen, Escócia, 1719 1796), Richard Whately (Londres, 1787-Dublin, Irlanda, 1863 e Hugh Blair (Edimbourg, Escócia, 1718-1800); três clérigos protestantes, são três dos mais proeminentes teóricos da chamada New Rhetoric. Obras mais destacadas; George Campbell, The Philosophy of Rhetoric (1776); Richard Whately, Elements of Rhetoric (1828), e Hugh Blair, Lectures on Rhetoric and Belles Lettres (1783). G. Campbell (Aberdeen, Escócia, 1719-1796) formado pela Universidade de Aberdeen, foi professor de teologia na mesma universidade, depois do Colégio Mareschal na mesma cidade. Linguista, tradutor, filósofo, teólogo. Richard Whately, nascido em Londres, 1787 e falecido em 1863, em Dublin, Irlanda; era economista, lógico e téologo. Foi Arcebispo Anglicano de Dublin. Hugh Blair nasceu e faleceu em Edimburgo, Escócia (1718-1800). Era ministro da Igreja da Escócia e ocupante da Cátedra de Retórica e Belles Lettres da Universidade de Edimburgo, autor e retórico, considerado um dos primeiros grandes teóricos do discurso escrito, com repercussões dentro e fora dos círculos religiosos.

23 "Psicologia" aqui deve ser entendida no sentido lato, incorporando uma parte do que tradicionalmente era considerada "teoria do conhecimento" e em parte "epistemologia".

${ }^{24}$ Escócia se uniu à Inglaterra em 1707 e pôs fim ao seu parlamento autônomo.

25 Outros nomes se projetaram para muito além das fronteiras escocesas, tais como Adam Smith, Thomas Reid e David Hume cuja relevância foi reafirmada pela polêmica com ele travada por Campbell. Hume havia publicado em 1748 o muito celebrado Educação em Revista|Belo Horizonte|v.37|e26782|2021
} 
considerados "moderados". Campbell foi um muito especial porta-voz da tolerância, da razão a serviço da fé contra os fanatismos religiosos tanto de católicos quanto de evangélicos. "Todos os seus sermões apelam ao senso comum dos ouvintes e evitam cuidadosamente qualquer apelo, seja qual for a superstição ou fanatismo" (McKAY, 1951, p. 88) ${ }^{26}$.

Em 1776, Campbell publicou pela primeira vez um livro em dois volumes, Philosophy of Rhetoric, que se tornaria internacionalmente conhecido dentro e fora dos círculos religiosos, e que o consagraria (McKAY, 1951). Os escritos de Campbell, assim como Adam Smith, Lord Karnes e Hugh Blair, se espalharam pela Escócia, por toda a Inglaterra, "e ajudaram a tornar a retórica um ramo principal de estudo em todas as faculdades americanas" (McCOSH, 1875, p. 241).

Nessa obra, além de discorrer sobre a eloquência, a retórica, a gramática, Campbell aprofunda seu entendimento a respeito da verdade lógica. Detalha os três níveis da "evidência intuitiva" - intelecção, consciência e senso comum/bom senso (common sense) -, bem como os níveis da "evidência dedutiva" e o "silogismo". É a "intuitiva" que aqui interessa.

A "intelecção", diz Campbell, é uma evidência de proposições tais como "um e quatro somam cinco" (CAMPBELL, 1808, p. 89). De fato, todos os axiomas da aritmética e da geometria estão incluídos nessa rubrica. Um segundo tipo que surge da "consciência", de onde "todo homem obtém a garantia perfeita de que ele tem sua própria existência" (CAMPBELL, 1808, p. 92). E um terceiro é o senso comum, chamado "uma fonte original de conhecimento comum a toda a humanidade" (CAMPBELL, 1808, p. 95).

Segundo Campbell, é grande a diferença entre esses tipos de "verdade intuitiva". Enquanto os axiomas matemáticos e as garantias da consciência são tão seguros que:

[...] a negação deles implica uma contradição manifesta, isso não é verdade quanto às verdades primárias da terceira ordem, o senso comum [...] "É necessário reconhecer que manter proposições, o inverso das verdades primárias do senso comum, não implica uma contradição, implica apenas insanidade." (CAMPBELL, 1808, p. 97)

A proeminência conferida ao "common sense" como garantia das verdades fornecidas pela razão e o alcance universal que lhe atribui projetaram George Campbell como um dos principais membros da escola de filosofia do senso comum (STANFORD ENCYCLOPEDIA OF PHILOSOPHY, 2017). À universalidade das verdades intuitivas, Campbell contrapõe as regras gramaticais: essas são sempre particulares. Contrapunha-se, portanto, à cartesiana gramática de PortRoyal.

É sobre as verdades intuitivas, o senso comum em especial, que o orador deve construir sua retórica e conquista sua audiência, seja pelo discurso escrito seja pelo discurso oral.

O débito à retórica e à chamada "psicologia" de George Campbell forneceram a Quacknebos a plataforma sobre a qual ele ergueu seu programa de ensino de retórica, da composição e da gramática. Forneceu-lhe o substrato para traduzir em manuais de ensino as operações para o bom manejo cotidiano da língua inglesa, escrita e oral.

Os estudos disponíveis relativos aos seus livros didáticos, destacadamente os primeiros de 1851 e 1854, fornecem provas convincentes do caráter inovador que Quackenbos imprimiu a seus materiais escolares e acadêmicos, em relação aos seus antecessores e coetâneos estadunidenses; mais do que isso, Quackenbos contribuiu grandemente para a criação de disciplinas destinadas ao ensino da composição e da retórica e, consequentemente, à renovação do ensino de gramática. No seu rastro,

Essay on Miracles. Campbell publicou em 1762 a sua Dissertation on Miracles na qual se opõe minuciosamente ao ceticismo de Hume em defesa de "evidências" miraculosas. Com a Dissertation..., a notoriedade de Campbell como filósofo/teólogo foi estendida além dos horizontes escoceses e serviu de apoio para a University of King's College lhe conferir, em 1764, o grau de "Doctor of Divinity".

${ }^{26}$ Em um escrito de 1789, Translation of the Gospels with Preliminary Dissertations and Note, considerada uma das suas melhores peças literárias, Campbell clama aos ouvintes: “O senso comum pede que, se Deus condescendeu em falar com o homem, é dever do homem atender ao que Ele diz; se, em qualquer escrito, Deus revelou Sua vontade ao homem, é dever do homem ler cuidadosamente esse escrito e fazer o possível para entendê-lo corretamente. O objetivo de todas as investigações das Escrituras, então, é apossar-se da verdade de Deus". 
surgiram outros autores e outros livros didáticos que reproduziram seu padrão, com maiores ou menores atualizações.

Uma vez identificado o débito de Quackenbos a Campbell, cabe ainda a complexa tarefa de identificar as raízes da sua relação com a pedagogia pestalozziana, especialmente com as lições de coisas (object-lessons), meio principal pela qual essa pedagogia se fez presente nas salas de aula estadunidenses incluindo, principalmente, seus artefatos.

Nas primeiras décadas do século XIX já se registram referências à pedagogia pestalozziana. Dos anos 1810 já constam viagens de estudos e estágios em escolas guiadas por essa pedagogia, tanto na Suíça, com o próprio Pestalozzi ou seus discípulos diretos, quanto em outros países, nos quais escolas afirmavam a incorporação das suas proposições educacionais e suas orientações para o trato da criança.

A forma mais tipicamente estadunidense de apropriação da pedagogia pestalozziana se deu, a partir de meados do século XIX, por meio do que passaram a denominar de "object-lessons" ou "object teaching", traduzido no Brasil por "lições de coisas".

O encontro de "lições de coisas" com a "nova retórica" parece ter se dado, no caso de Quackenbos, na confecção de Illustrated lessons... Nos livrinhos anteriores - relativos à temática, frise-se não se encontram referências àquela sistemática de trabalho. Cabem algumas hipóteses para o tal encontro ter se dado no livrinho de 1876 e somente naquele momento: àquela altura, Quackenbos já competia, na "América", com muitas publicações que declaravam adoção às "lições de coisas" que haviam se tornado a grande voga nas escolas públicas elementares a partir de meados dos anos de 1860, quando da construção da nação unificada pela vitória do Norte sobre o Sul, ao final da Guerra Civil. Assim, mercadologicamente, Quackenbos precisava conquistar o público declarando adesão a Pestalozzi e àquela metodologia considerada a fiel tradução do pestalozzismo. Quackenbos pela primeira vez lançava um livro didático destinado exatamente para os alunos pequenos considerados, então, a clientela cativa da pedagogia pestalozziana. A grande prova da adoção do ensino pelas coisas, pela experiência, era expressa por meio da incorporação de ilustrações de cenas às lições. Antes, Quackenbos não as havia utilizado para ensinar gramática, retórica ou composição. Não é casual, portanto, que o destaque no título do livro é conferido às ilustrações contidas nas lições lá reunidas.

Não é desprezível, também, o fato de que, naquela altura, os livros iniciais que Quackenbos lançara em 1851 e 1854, já estarem perdendo audiência para novas propostas de ensino, particularmente da retórica.

Há que se considerar, ainda, a hipótese, quiçá mais central, de que Quackenbos tenha entendido que o método de "lições de coisas" continha o mesmo substrato filosófico que ele vislumbrara na retórica aprendida com Blair e, em especial, com Campbell: o chamamento à experiência, à vida imediata, o apelo ao empírico..., assim como o caminho do conhecimento via intuição e a indução, como já exposto anteriormente. Agora, tratava-se de ir às "coisas", não às ideias; lembrando que, assim como essas, aquelas se apresentam à mente por meio de palavras.

\section{CONSIDERAÇÕES FINAIS}

Elaborado na perspectiva de que à legislação cabia funcionar como instrumento central das mudanças socioculturais, o parecer de Ruy Barbosa, em especial no que tange aos livros aqui destacados, compõe importante peça nas disputas em torno do ensino da língua portuguesa na escola primária Oitocentista, mediante defesa de renovação desse ensino a partir dos "modernos" princípios pedagógicos e linguísticos disseminados no Brasil do final do século XIX.

Ao eleger Grammatica analytica... como exemplo dos delitos cometidos no ensino da língua e Illustrated lessons... como antídoto para se fazer renovar esse ensino a exemplo dos progressos já testados em outras localidades, Ruy Barbosa credita ao método intuitivo a missão de efetivar a modernidade em Educação no Brasil, ao mesmo tempo em que denuncia e se posiciona contrário ao conservadorismo linguístico, pedagógico e administrativo presentes na Instrução Primária e Secundária da Corte. A análise desses livros por Ruy Barbosa exemplifica o obscurantismo presente nas escolas da Corte no final do século XIX e indica caminho a ser trilhado na renovação pedagógica. 
Nesse sentido, o delito destacado por Ruy Barbosa por meio da gramática de Ortiz e Pardal, adotada pelo Governo Imperial em 1872 para substituir a gramática de Cyrillo Dilermando da Silveira, são reforçados justamente porque a aprovação daquele livro não representou qualquer tipo de renovação no ensino até então posto. Muito pelo contrário, na contramão da renovação científica da Linguística, de orientação histórico-comparativa, que ganhava força na segunda metade do século XIX, Grammatica analytica... se manteve calcada na perspectiva da gramática geral e filosófica de modelo greco-latino, fundada na "arte" de ensinar as virtudes do falar e do escrever bem.

A esse problema se soma o do ensino da gramática no curso primário. Conforme argumenta Barbosa, desde a década de 1860 o estudo "scientífico" da língua era aplicado em países como França e Alemanha apenas para as "derradeiras" classes. Para o curso primário devia se ofertar estudo prático da língua, que conduzisse o alunado ao conhecimento "natural" da gramática. Ou seja, proposição muito diferente da concretizada na gramática de Ortiz de Pardal, que já pelo seu título indicava, pela expressão "analytica", o intento de uma gramática descritiva e prescritiva, apoiada na definição e explicação de conceitos e leis gramaticais.

Esses aspectos possibilitam presumir que a substituição da gramática de Dilermando da Silveira pela de Ortiz e Pardal não se deu na esteira de qualquer debate pedagógico ou necessidade de mudanças no ensino até então posto nas escolas da capital do Império. Muito possivelmente essa alteração se deu em função da projeção de que Pardal gozava na administração da Instrução Pública da Corte e dos cargos que nela ocupava, dentre os quais, o de membro do Conselho Diretor da Inspetoria Geral da Instrução Primária e Secundária, ao qual cabia rever todos os livros adotados no município do Rio de Janeiro, fazê-los corrigir e, se necessário, substituí-los por novos livros.

Apesar das críticas, a Grammatica analytica... continuou circulando por mais um tempo pelas mãos de adultos e crianças; mas aparentemente foi enterrada, antes da última década do século XIX, pela propaganda em favor do método intuitivo e pelo lançamento de novos títulos afeitos a esse método. Mas os elogios de Ruy Barbosa às lições ilustradas de Quackenbos não foram suficientes para colocá-las em circulação nos meios escolares brasileiros e nem para plantar o nome do autor entre os gramáticos e professores de gramática daquele final de Império; pelo menos é o que indicam os levantamentos efetuados até o momento. Buscas mais extensas poderão fornecer novas pistas, inclusive da circulação do nome de Quackenbos como inovador no ensino da Aritmética e dos caminhos que teriam levado Ruy Barbosa a conhecer esse herdeiro estadunidense do "enlightenment" escocês.

\section{REFERÊNCIAS}

BARBOSA, Ruy. Reforma do ensino primário e várias instituições complementares da instrucção pública. Parecer e projecto da Commissão de Instrucção Publica composta dos deputados Ruy Barbosa, Thomaz Bonfim Espínola e Ulysses Machado Pereira Vianna. Rio de Janeiro: Typographia Nacional, 1883.

BASTOS, Maria Helena C. As Conferências Pedagógicas dos professores primários no Município da Corte: permuta das luzes e idéias (1873-1886?). In: XXII SIMPÓSIO NACIONAL DE HISTÓRIA ANPUH, 2003, João Pessoa. Anais.... João Pessoa: UFPB, 2003, s/p.

BASTOS, Maria Helena C. Ferdinand Buisson no Brasil: pistas, vestígios e sinais de suas ideias pedagógicas (1870-1900). Revista História da Educação, v. 4, n. 8, p. 79-109, 2000.

BASTOS, Maria Helena C. Leituras da Ilustração Brasileira: Célestin Hippeau (1803-1883). Revista Brasileira de História da Educação, n. 3, p. 67-112, 2002.

BASTOS, Maria Helena C. Método intuitivo e lições de coisas por Ferdinand Buisson. Revista História da Educação, v. 17, n. 39, p. 231-253, 2013. 
BECHTEL, Donald L. An Analysis of Selected Civic Attitudes in High School American History, Geography, and Civic Textbooks, 1885-1914. 1968. 265f. Dissertation (Doctor of Education) University of South Dakota, Vermillion,1968.

BLAIR, Hugh. Lectures on Rhetoric and Belles Lettres. London; Edinburgh: W. Strahan; T. Cadell ..., and W. Creech, 1783.

BLAKE, Augusto V. A. Sacramento. Dicionario bibliographico brazileiro. Rio de Janeiro: Typographia Nacional, 1899.

BORGES, Angélica. A urdidura do magistério primário na Corte Imperial: um professor na trama de relações e agências. 2014. 415f. Tese (Doutorado em Educação) - Faculdade de Educação, USP, São Paulo, 2014.

BORGES, Angélica. Ordem no ensino: A inspeção de professores primários na Capital do Império brasileiro (1854-1865). 2008. 287f. Dissertação (Mestrado em Educação) - Programa de Pós-graduação em Educação, UERJ, Rio de Janeiro, 2008.

BRASIL. Ministério do Império. Relatório do anno de 1872 apresentado á Assembleia Geral na $1^{\mathrm{a}}$ sessão da 15 ${ }^{\text {a }}$ legislatura. Rio de Janeiro: Typografia Nacional, 1872. Disponível em:

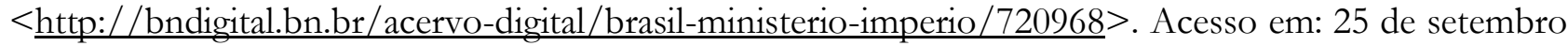
de 2020.

BRASIL. Ministério do Império. Relatório do anno de 1872 apresentado á Assembleia Geral na $2^{\mathbf{a}}$ sessão da $15^{\text {a }}$ legislatura. Rio de Janeiro: Typografia Nacional, 1873. Disponível em: $<$ http://bndigital.bn.br/acervo-digital/brasil-ministerio-imperio/720968 $>$. Acesso em: 25 de setembro de 2020.

CAMPBELL, George. The Philosophy of Rhetoric. Vol. I. Edinburgh: George Ramsay \& Co. 1808 (1776).

CASTILHO, Ataliba T. Estudos lingüísticos no Brasil. Notas para sua história. Alfa, n. 2, p. 35-143, 1962.

ENOS, Theresa (ed.). Encyclopedia of Rhetoric and Composition. Communication from Ancient Times to the Information Age. New York, London: Routledge, 2011.

HANE, Mikiso. English Liberalism and the Japonese Enlightnment, 1868-1890. 1957. 320. Dissertation (Doctor of Philosophy) - Faculty of the Graduate Schhol, Yale University, New Haven, 1957.

LEMOS, Daniel Cavalcanti A. O discurso da ordem: A constituição do campo docente na Corte Imperial. 2006. 189f. Dissertação (Mestrado em Educação), Rio de Janeiro, Programa de Pós-graduação em Educação, UERJ, 2006.

LEMOS, Daniel Cavalcanti A. Professores em movimento: A Emergência do associativismo docente na Corte Imperial. 2011. 545f. Tese (Doutorado em Educação) - Belo Horizonte, Programa de Pósgraduação em Educação, UFMG, 2011.

LOURENÇO FILHO, Manoel B. A pedagogia de Rui Barbosa. Brasília: INEP/MEC, 1954.

MARTINEZ, Alessandra F. Educar e instruir: a instrução pública na Corte Imperial (1870-1889). 1998. 241f. Dissertação (Mestrado em História) - Niterói, Programa de Pós-graduação em História, UFF, 1998. 
MARTINS, Antonio F. Relatório da Inspectoria Geral da Instrucção Primaria e Secundaria do Municipio da Corte. Rio de Janeiro: Typographia, 1874. (Apresentado em 18 de abril de 1874 ao Ilmo. e Exm. Sr. Conselheiro João Alfredo Corrêa de Oliveira, Ministro e secretario d'estado dos negócios do império).

McCOSH, James. The Scottish Philosophy, Biographical, Expository, Critical, From Hutcheson to Hamilton. New York: Robert Carter and Brothers, 1875.

McKAY, Arthur Raymond. George Campbell (1719-1796), His Life and Thought. Thesis (Doctor of Philosophy and Theology) - University of Edinburgh, Edinburgh, 1951.

NEW ENGLAND JOURNAL OF EDUCATION, v. 4, n. 5, August 12, 1876.

NISHIHIRA, Isao. Western Influences on the Modernization of Japonese Education, 1868-1912. 1972. 485f. Dissertation (Doctor of Philosophy) - The Ohio State University, Columbus, 1972.

ORTIZ, José; PARDAL, Candido Matheus de Faria. Grammatica analytica e explicativa da Lingua Portugueza. $5^{\text {a }}$ ed. Rio de Janeiro: Livraria Nicolau-Alves, 1884 (1871).

PARDAL, Candido Matheus de Faria. Resposta do Professor Candido Matheus de Faria Pardal. In: BRASIL. Ministério do Império. Relatório do anno de 1872 apresentado á Assembleia Geral na $2^{\mathbf{a}}$ sessão da $15^{\mathbf{a}}$ legislatura. Rio de Janeiro: Typografia Nacional, 1873. Disponível em: $<$ http://bndigital.bn.br/acervo-digital/brasil-ministerio-imperio/720968 $>$. Acesso em: 25 de setembro de 2020.

PIROLA, André Luiz B.. Lutas, leis e livros: professores de História na história do ensino no Espírito Santo (1850-1950). 2013. 275f. Tese (Doutorado em Educação) - Programa de Estudos Pós-graduados em Educação: História, Política, Sociedade, PUC-SP, São Paulo, 2013.

POLACHINI, Bruna Soares. O tratamento da sintaxe em gramáticas brasileira do século XIX: estudo historiográfico. 2013. 221f. Dissertação (Mestrado em Semiótica e Linguística) - São Paulo, Faculdade de Filosofia, Ciências, Letras e Ciências Humanas, USP, 2013.

POLACHINI, Bruna Soares. Uma história serial e conceitual da gramática brasileira oitocentista de língua portuguesa. 2018. 457f. Tese (Doutorado em Semiótica e Linguística Geral) - São Paulo, Faculdade de Filosofia, Ciências, Letras e Ciências Humanas, USP, 2018.

QUACKENBOS, George Payn. Illustrated lessons in our lenguage; or how to speak and write correctly. Designed to teach english grammar, without technicalities. New York: D. Appleton \& Company, 1876.

QUACKENBOS, George Payn. Advanced course of composition and rhetoric: a series of practial lessons on the origin, history, and peculiarities of the English language...Adapted to selfinstruction, and the use of schools and colleges. New York: D. Applçeton \& Company, 1864 (1854).

QUACKENBOS, George Payn. First lessons in composition, in which the principles of the art are developed in connection with the principles of grammar; embracing full directions on the subject of punctuation; with copious exercises. New York: D. Applçeton \& Company, 1851. 
TEIXEIRA, Giselle B.; SCHUELER, Alessandra F. Livros para a escola primária carioca no século XIX: produção, circulação e adoção de textos escolares de professores. Revista Brasileira de História da Educação, n. 20, p. 137-164, 2009.

SCHULTZ, Lucille M. The Young Composers: Composition's Beginnings in Nineteenth-Century Schools. Studies in Writing and Rhetoric. Carbondale: Southern Illinois University Press, 1999. Disponível em: <www.siu.edu/-siupress>. Acesso em: 12 de agosto de 2020.

SPIERS, Alexander; QUACKENBOS, George Payn. Spiers and Surenne's French and English pronouncing dictionary: newly composed from the French dictionaries of the French Academy, Laveaux, Boiste, Bescherelle, Landais, etc., and from the English dictionaries of Johnson, Webster, Worcester, Richardson, etc. D. Appleton \& Company, 1912 (1852).

STANFORD ENCYCLOPEDIA OF PHILOSOPHY. Scottish Philosophy in the 18th Century. First published Wed Jun 27, 2001; substantive revision Fri Sep 22, 2017. Disponível em: $<$ https://plato.stanford.edu/entries/scottish-18th/> Último acesso: 03 de dezembro de 2020.

TEIVE AURAS, Gladys Mary G. Manual de lições de coisas de Norman Calkins: operacionalizando a forma intuitiva de ensinar e de aprender. Sarmiento, nº 11, p. 79-92, 2007.

TEIXEIRA, Giselle Baptista. A imprensa pedagógica no Rio de Janeiro: os jornais e as revistas como agentes transformadores da escola (1870-1919). 2016. 350f. Tese (Doutorado em Educação). Niterói: UFF, 2016.

TEIXEIRA, Giselle Baptista. O grande mestre da escola: os livros de leitura para a escola primária da capital do Império Brasileiro. 2008. 237f. Dissertação (Mestrado em Educação) - Rio de Janeiro, Faculdade de Educação, Universidade do Estado do Rio de Janeiro, 2008.

UNITED STATES BUREAU OF EDUCATION (THE). Report of The Comissioner of Education for The Year 1898-1899. Vol. 1. Washington: Government Printing Office, 1900.

VALDEMARIN, VeraTeresa. Circulação de modelos para o ensino de Ciências Naturais: o método de ensino intuitivo na transição entre Império e República. Cadernos de História da Educação, v.19, n ${ }^{\circ}$ 3, p. 1033-1050, 2020.

VALDEMARIN, VeraTeresa. Ensino da leitura no método intuitivo: as palavras como unidade de compreensão e sentido. Educar, no 18, p. 157-182, 2001.

VALDEMARIN, VeraTeresa. Lições de coisas: Concepção científica e projeto modernizador para a sociedade. Cadernos Cedes, ano XIX, no52, p. 74-87, 2000 b.

VALDEMARIN, Vera'Teresa. Método intuitivo: Os sentidos como janelas e portas que se abrem para um mundo interpretado. In: SOUZA, R.F.; VALDEMARIN. V.T. e ALMEIDA, J.S. O legado educacional do século XIX. Araraquara: FCL/Unesp, 1998, p. 63-106.

VALDEMARIN, VeraTeresa. O liberalismo demiurgo. São Paulo: Cultura Acadêmica, 2000a.

VALENTE, Wagner Rodrigues. Como Ensinar Matemática no Curso Primário? Uma questão de conteúdos e métodos, 1890-1930. Perspectivas da Educação Matemática, v. 8, n 17, p. 192-207, 2015. 
WELSCH, Kathleen Ann. Nineteenth-century composition: The relationship between pedagogical concerns and cultural values in American colleges, 1850-1890. Dissertation (Doctor of Philosophy). Pittsburgh: University of Pittsburgh, 1994.

WHATELY, Richard. Elements of Rhetoric. Louisville, Ky. : Morton \& Griswold, 1858 (1828).

Submetido: $20 / 12 / 2020$

Aprovado: 05/03/2021 